ENTRY INTO NEW NICHES: THE EFFECTS OF FIRM AGE AND THE EXPANSION OF TECHNOLOGICAL CAPABILITIES ON INNOVATIVE OUTPUT AND IMPACT

\author{
REDDI KOTHA \\ Lee Kong Chian School of Business \\ Singapore Management University \\ 50 Stamford Road \\ 178899, Singapore \\ 6568280401 \\ 6568280777 (fax) \\ reddikotha@smu.edu.sg \\ YANFENG ZHENG \\ CLEMSON UNIVERSITY \\ College of Business \\ 165 Sirrine Hall, \\ Clemson, SC 29634 \\ 864-656-1573 \\ yanfenz@clemson.edu
GERARD GEORGE
Business School
South Kensington, SW7 2AZ
London, U.K.
$44(0) 2075941876$
44 (0)20 75945915 (fax)
g.george@imperial.ac.uk \\ IMPERIAL COLLEGE LONDON \\ Contact Author: Gerard George
}

KEYWORDS: Capabilities, Biotechnology, Age, Innovation, Entry, Patents

ACCEPTED FOR PUBLICATION AT STRATEGIC MANAGEMENT JOURNAL

JUNE 2010 


\title{
ENTRY INTO NEW NICHES: THE EFFECTS OF FIRM AGE AND THE EXPANSION OF TECHNOLOGICAL CAPABILITIES ON INNOVATIVE OUTPUT AND IMPACT
}

\begin{abstract}
We provide evidence that young firms systematically differ from older firms in their innovative output when they enter 'new to the firm' technological niches. We analyze data from 128 biotechnology firms since their inception and track these firms over time. Our analyses reveal that the organizational age at which the firm branches into new technological niches significantly influences its innovative activity. We refine the focus of the extant literature by separately examining the effects of branching on the quantity of innovative output, and the impact that this output has on the technology domain. Subsequent to branching into new niches, we find that older firms have a higher quantity of output than their younger counterparts; whereas young firms tend to outpace their older rivals with higher impact. The implications of these findings for the literature on dynamic capabilities and entrepreneurship are discussed.
\end{abstract}


How does the timing of capability development matter? We examine whether the benefits that accrue to expanding technological capabilities are contingent upon firm age. We draw on the organizational aging and dynamic capability literatures to study how the expansion of a firm's capabilities by entering 'new to the firm' technological niches, termed as branching, at different points in the firm's age would vary in its influence on subsequent innovative activity. Though commonly assumed that startups create breakthrough inventions, some contrarian evidence suggests that mature incumbents also generate such discoveries (Dushnitsky and Lenox, 2005; Phene et al., 2006). In a study of large chemical firms, Ahuja and Lampert (2001) proffer evidence to suggest that mature incumbents overcome pathologies of aging by branching into new domains and by recombining new with old knowledge. Other researchers have investigated the temporal and structural effects of recombining new with old knowledge on innovative output (Nerkar, 2003; Rosenkopf and Nerkar, 2001; Rothaermel and Boeker, 2008; Yayavaram and Ahuja, 2008). We contribute to this conversation by examining the role of entry into novel technology areas, i.e. branching, and how the effects of branching on innovative activity vary with firm age.

To examine whether the pattern of optimal technological expansion is conditional on firm age, we study innovative output of biotechnology firms from their inception over a twenty year period. This sample allows us to investigate the underlying conditions when firms optimize their output and impact by managing entry into new technological niches. The study engages the literature on capability development, especially in young firms. The entry into new niches corresponds with the expansion of a firm's technological capabilities to drive innovation within and across these technological domains. We also refine the focus of the extant literature by 
separately examining the effects of branching on the quantity of innovative output and the impact that the output has on the technology domain.

\section{Branching, Recombination, and Innovation}

Scholars have posited that new knowledge is created by unique recombination of existing knowledge repositories (Basalla, 1988; Henderson and Cockburn, 1994; Schumpeter, 1939). Though inventors can possibly combine any prevalent technological components, what actually gets combined is constrained by the localness of their search and the social construction on what components can be gainfully combined. Branching into a 'new to the firm' technology domain increases the stock of opportunities to which the firm has access (Fleming, 2001; Fleming and Sorenson, 2004). The knowledge components that the firm acquires in the new domain can then be recombined with its existing knowledge to introduce heterogeneity that facilitates problem solving (Amabile, 1988; George, Kotha and Zheng, 2008). The variety in problem solving approaches increases the likelihood that solutions can be found for technological bottlenecks. Recombination can also enhance the impact of the innovation on the technology domain itself. Indeed, it has been argued that breakthroughs result from recombining non-obvious technology components (Basalla, 1988). Hence, when a firm branches, it could combine new knowledge with its existing knowledge to yield radical innovation (Ahuja and Lampert, 2001; Katila and Ahuja, 2002) that can potentially influence both domains (Ethiraj and Puranam, 2004).

Though searching widely for technology solutions has positive implications, extensive experimentation without deep understanding of the causal relationships between components may prove counterproductive (George et al., 2008; Lee et al., 2004; Yayavaram and Ahuja, 2008). Entering multiple new technological niches simultaneously necessitates experimentation to understand the technology domains and their underlying science. Excessive experimentation 
can hurt output and quality by reducing reliability (March, 1991). To create impact, firms will need to develop a deeper understanding of the new technical field that they enter in order to build on existing knowledge. When firms concurrently enter multiple domains, it becomes difficult to absorb knowledge (Cohen and Levinthal, 1990), likely reducing novelty and impact because they fail to invest in maximizing contributions to the multiple technological fields that they enter. Assimilating knowledge is time-consuming and expensive; a luxury ill-afforded by firms that are resource constrained because processing knowledge for multiple domains likely increases the coordination cost multifold. Consequently, we expect a curvilinear relationship between branching and innovative output and its impact on the technology field, such that moderate branching is better than low or high branching for the count of innovative output and its impact on the technology field.

Hypothesis 1a: The relationship between the number of entries into new technological niches (branching) and the quantity of innovative output is curvilinear (inverted $U$ shaped) such that moderate branching yields optimal outcomes.

Hypothesis 1b: The relationship between the number of entries into new technological niches (branching) and the technological impact of the innovative output is curvilinear (inverted U-shaped) such that moderate branching yields optimal outcomes.

\section{Branching, Firm Age, and Innovation}

We posit that the relative benefit that accrues to the firm's branching activity systematically differs by the age at which the firm undertakes this capability expansion. The causal mechanisms that underlie the differences in effects of branching by firm age can be traced to the tension that arises from efficiencies in learning from cumulative output versus the rigidities that occur with senescence (Argote, 1999; Barron, West and Hannan, 1994). Scholars have argued that a firm's competence to increase production output improves with age because the firm benefits from well-embedded, robust routines derived from prior operating experiences 
(Nelson and Winter, 1982). Similarly, Cohen and Levinthal (1990) found that accumulation of knowledge enhances a firm's ability to acquire, assimilate and exploit information to generate further innovations.

In addition, a firm's resource endowment, especially its slack resources, may positively influence innovative output (Nohria and Gulati, 1996) and encourage it to explore new areas for growth (Penrose, 1959). When a firm branches into a new technological niche, the slack allows it to divert free resources towards integrating new knowledge with existing knowledge repositories to increase innovative output. Also, the presence of an infrastructure to innovate such as research laboratories and scientific human capital, increase the potential for a firm to absorb information (Zucker, Darby and Brewer, 1998). Since older firms are more likely to have accumulated experience and slack resources (Penrose, 1959), we expect that they stand to benefit more from branching into new niches than younger firms. Also, older firms are likely to have routinized search strategies which further improve innovative output (Nelson and Winter, 1982; Ronsenkopf and Nerkar, 2001). On the contrary, younger firms suffer from severe resource constraints and lack the efficiency-enhancing experience (George, 2005; Stinchcombe, 1965). Collectively, these arguments suggest that older firms are likely to yield higher innovative output than younger firms when they branch into new niches.

Hypothesis 2a: The number of entries into new technological niches (branching) is more positively related to innovative output for older firms than for younger firms.

Whereas resource and experience arguments favor older firms and their innovative output, the impact of such output on the technological domain is likely driven by a different causal dynamic. First, in older firms, as experience in a technology accumulates, the cognitive maps of scientists and managers become increasingly rigid where paradigmatic solutions are likely to further confound problems (March, 1991). In examining letters to shareholders of the 15 
largest pharmaceutical firms, Kaplan, Murray and Henderson (2003) found that the mental models of senior management are partially responsible for the difficulties these firms faced when responding to technological discontinuities. Others argue that older firms possess informationprocessing routines that encourage innovation in their existing technology trajectories rather than in new technological fields (Henderson, 1993; Nerkar, 2003). Older firms are also likely to be constrained by ossified routines and structures that hinder exploration (Nelson \& Winter, 1982). Because heterogeneity in problem solving techniques is an important source of novel solutions (Amabile, 1988), rigid mental models and deeply embedded routines serve to naturally limit the mature firm's foray into producing high impact innovation.

The presence of dominant coalitions and difficulties in sharing information in older firms may favor younger firms that have greater flexibility when entering technological niches. In older firms, entry into new technology domains is unlikely to receive support from the dominant coalitions. Consequently, managers may under-allocate resources towards integrating new knowledge, which, in turn could curtail the explorative tendencies of their scientists' search for new knowledge (Henderson, 1993; Kaplan et al., 2003; Pisano, 1994). Finally, the communication of tacit technological information is critical to innovation (Cohen and Levinthal, 1990). Communication in a small firm is easier as the number of employees is fewer and decision making systems are fluid and transparent, which allows for rich communication and cohesion in the management team (Mosakowski, 1998). Fan (2010) finds that younger firms that focused on explorative activities were more likely to survive. These factors suggest that tacit knowledge-driven innovation has a more favorable environment in younger firms than in older firms. 
The advantage that accrues to young firms vis-à-vis older firms in producing high impact innovation has one important constraint. Younger firms are less likely to have the absorptive capacity that mature firms possess. With experience, the organization develops an understanding of its technological domain and can recognize optimal conditions for recombination (Zahra and George, 2002). These firms develop a comprehension of the limits to component recombination either through their own technology efforts or by observing others (Henderson and Cockburn, 1994; Powell et al., 1996). This experience helps older firms avoid 'dead-ends' and makes them less likely to pursue fruitless innovation.

However, we expect that, on average, the relative benefit of higher absorptive capacity is outweighed by the problems of rigid mental models, dominant coalitions, and restricted communication channels that decrease the likelihood of high impact innovation in older firms. Young startups may have lower absorptive capacity but are nimble in their decision-making, are less constrained by routines, have fewer problems with managerial coalitions (Mosakowski, 1998), and have communication channels that foster a climate for problem solving and creativity (Whiting, 1988), which contribute to developing innovative output with high impact (Gilad, 1984). Therefore, we posit that branching is likely to enhance the technological impact of the firm's innovative output for younger firms more than for older firms.

Hypothesis 2b: The number of entries into new technological niches (branching) is more positively related to impact (the innovative output has on the technology field) for younger firms than older firms.

Two aspects of our hypotheses merit clarification. First, our moderation arguments suggest that increases in output and impact are higher for older and younger firms respectively. Specifically, the change in output for older firms exceeds the corresponding change in younger firms as branching increases (i.e. slope is steeper for older firms' output). Conversely, the change 
in impact for younger firms exceeds the corresponding increase for older firms (i.e. slope is steeper for younger firms' impact). Second, the differences in slopes for younger and older firms subsequent to branching are tempered by the main effect of branching. The main effect of branching is curvilinear, i.e. moderate branching yields the highest output and impact. Would the curvilinear relationship of the main effect of branching on impact and output shift uniformly upwards for older firms for output and for younger firms for impact? Ex ante there is no precise guidance of the level of branching when moderation is highest. Our predictions suggest that, on average, we will have a positive moderation of firm age on branching and output and negative moderation on impact respectively.

\section{METHOD}

\section{Sample}

We collected longitudinal data on startups in the biotechnology industry. The biotechnology industry refers to the manipulation of genetic material through recombinant DNA technology, cell fusion and monoclonal antibodies. Biotechnology is an appropriate context to test theories of innovation as performance is largely dependent upon the firms' technological capabilities (Phene et al. 2006; Sorensen and Stuart, 2000; Huang and Murray, 2009). We follow Shan, Walker and Kogut (1994) to restrict the sample to firms in human diagnostics and therapeutics, enabling us to compare firms in a relatively homogeneous sector. We developed a list of companies from the 1997 GEN Guides to Biotechnology Companies, a comprehensive biotechnology industry list. From this set, we selected the publicly traded firms and then tracked them back through to their initial founding years, consistent with other studies (George et al., 2002; Lerner, 1994; Shan et al., 1994; Pisano, 1994). This yielded a sample size of 151 publicly traded firms. For these firms, we collected historic data since their founding years using Bioscan, 
Compustat, initial public offering (IPO) disclosure filings, firm websites, and US Patent and Trademark Office (USPTO) data on patents. We could collect complete data for 128 firms for firms between 1980 and 1999. We curtail our sample to 1999 because it allows 20 years of observation window and also because when we first constructed the database we were limited by the data supplied by National Bureau of Economic Research (NBER) which was until 1999. We then updated the patent forward citation data until 2006 using USPTO data to avoid censoring problems.

\section{Technological capabilities}

We use patent data to track technological capability development within organizations. Patent data were drawn from the NBER database that contains a total of 2.9 million patents issued between 1963 and 1999 (Hall, Jaffe and Trajtenberg, 2005). Patent filing year, patent class, assignee names, number of sub-classes, and number of claims were used to construct our patent data. Whereas patents have been used to identify outcomes of R\&D activities, patents have been also used extensively to capture the technological capabilities or portfolios (Argyres and Silverman, 2004; Sampson, 2005; Zheng, Liu and George, 2010).

\section{Dependent variables}

Quantity of Innovative Output is measured as the number of new patents applied for in two subsequent years $(t+1, t+2)$. Use of patents to study firm-level innovativeness is common (Ahuja and Lampert, 2001; Stuart, 2000). Drug development comprises a complex approval process, where the entire process averages twelve years. Consequently, correlating entry into new technology domains with product introduction may prove futile. Also, capital markets are able to value influential patents when they are granted (Hall, Jaffe and Trajtenberg, 2005). Therefore, patent output and citations not only allow us to track knowledge usage and creation but are also 
correlated with the economic value of the firm. The criteria for receiving a patent, as described by the USPTO, are that each invention should be novel, non-trivial, and have commercial application. The innovative output variable has an average value of 4.50 and standard deviation of 13.2.

Technological Impact is measured as the average number of citations, net of self citations, received by patents filed by the firm in years $t+1$ and $t+2$ (citations received/count of patents) observed in five subsequent years ( $t+2$ to $t+6$ and $t+3$ to $t+7$ respectively). Most patent citations tend to occur within a few years after the grant date, peaking at the year three. Hence, our use of a five-year window does not cause significant right censoring bias (Hall et al., 2001). To reduce the overlap with the innovative output measure, we divide the total citations received by technology output. The impact variable has an average value of 4.2 and standard deviation of 14.2.

\section{Independent variables}

Branching is a count of the number of entries by a firm into 'new to the firm' niches measured at the patent main class level, consistent with Ahuja and Lampert (2001). We use the 3digit main classification followed by USPTO to identify technology domains. This measure reflects the process of expanding the scope of a firm's technological expertise. Corresponding to the two year window for our dependent variables, we use the number of branching entries made by a firm in year $\mathrm{t}-0$ and $\mathrm{t}-1$. The mean branching with the two-year window is 0.7 and has a maximum value of 9 . Our results are robust to using a one- or three-year prior window of branching.

Firm Age was measured as the number of years since incorporation. The data source for the founding year was Bioscan for the years 1988 to 2003. In a few cases where founding information was missing in Bioscan, we used company website information to find the year.

\section{Control variables}


Distance. ${ }^{l}$ To measure the proximity of technology branching by a firm we follow the technique used by Rosenkopf and Almeida (2003). For each patent, we tabulated the technological classes to which the patent was assigned. Aggregating the set of patents for each firm by year, we summarized the percentage of assignments in each patent class. We then calculated the Euclidean distances between these patent class vectors for each firm by comparing it to the preceding year. This distance measure ranged from zero (firms with identical patenting profiles compared to past) to 1.4 (the square root of two, where the firm continues to patent in the same classes, and each firm is active in a different class).

Knowledge Stock is the number of patents applied in the previous three years. This measure helps control for resource availability and size of the firm. We used the Griliches (1990) deflator for knowledge stock that gives lower weights for the previous two years $(0.8,0.6)$, suggesting that recent patents have more influence on new applications than older patents.

Achieved IPO is a time variant dummy variable that tracks if a firm achieved its initial public offering (IPO) in the financial markets. Since we track firms beginning at their founding year, we do not have access to data on firm size (such as assets or employees). Achieving the IPO provides a proxy for size and resource access.

Breadth and Depth of Technological Capabilities. Breadth is measured as the total number of technological classes in which a firm applied for patents, prior to the time window for the construction of the branching variable. Depth is the maximum number of patents in any one technological class as defined by the USPTO (Argyres and Silverman, 2004).

Alliances. We control for the role of alliances on innovative output (Powell et al., 2005). We measure the number of prior alliances in that year (t0). In addition, we include a control for

\footnotetext{
${ }^{1}$ We thank an anonymous reviewer for suggesting an alternative strategy to construct branching distance to the citation based method used in a prior version of the manuscript.
} 
the total prior alliances formed before the past year (t-1..t-n; where $n$ is the firm founding year). The primary source of alliance information is rDNA.com; we corroborated these data with Bioscan and SEC filings.

\section{Estimation}

For all estimations, we use a panel of firm-year observations. We use Fixed Effect Poisson regression estimation for the count data (Wooldridge, 2001). We report the results of a fixed-effects model that controls for firm-level invariant effects that accounts for both the timeseries observations and the nature of the dependent variables. In addition, we use multiple lagged variables to parse out the temporal effects for capturing changes in technological capabilities. We predict innovative output for two subsequent years $(t+1, t+2)$ because capability development may take time to materialize making it more difficult to capture in annual spells. Additionally, we analyze models with a 3-year window and the results remained consistent with those reported. Given the use of quadratic terms and their interactions, multicollinearity is a possible concern. Cohen et al. (2003) prescribe testing the joint significance of highly correlated variables if their coefficients are not significant. With the interaction terms and their interpretation, we follow their recommendation in plotting values and not extrapolating beyond the data points observed in our sample.

\section{Robustness}

Our sampling frame includes firms that went public; although this strategy is used in prior studies (e.g., Phene et al., 2006; Shan et al., 2004; Sorensen and Stuart, 2000), this could bias our sample to firms that undertook a risky strategy of entering new niches and survived. To address this problem, we use a Heckman correction model followed by Gulati and Higgins (2003). We find that the first-stage model is significant and the selection hazard ratio is also 
significant in the second-stage model. This suggests that sampling on surviving firms may indeed lead to over estimation of the innovative activity. We include this correction in our estimation and can say with a degree of confidence that our results are robust to survival bias. We do not report these estimations because we use random effects models to specify the second stage sample selection variable, as it is a firm level, time invariant variable. The pattern of results is similar when we use fixed effects or random effects models implying that correcting for sample selection does not change the pattern of results. We also run the Hausman test to check the difference in using fixed effects and random effects estimations. We find that the test is not significant indicating that using random effects may also be appropriate.

Furthermore, we conducted sensitivity analysis for the exclusion of outliers. We find that excluding outliers does not change the significance of results for the theory variables. Also, we checked for robustness with different conceptualizations of technological impact. We use a simple count of citations received, net of self-citations, to compare with the average number of citations received. These results are qualitatively similar and, in some cases, have greater statistical significance than the average number of citations used to test our hypotheses.

Endogeneity. Our theory is conditional on the fact that a firm enters into a new domain, i.e. it branches. Branching may be a strategic choice by a firm, which introduces a potential endogeneity issue. Since there is no widely used standard estimation for endogeneity correction for fixed effects Poisson models, we follow a method used by Ahuja and Lahiri (2006). In the first stage, we estimated a probit model where the dependent variable takes the value of 1 if the firm branches and otherwise 0 . To estimate the first-stage equation, we need time varying covariates that predict why some firms branch (and not others). These covariates should typically be exogenous to the decision makers and the firms i.e. not in the control of managers. We use 
three exogenous variables constructed from longitudinal data of venture capital investment in biotechnology to serve as identifiers for the first stage model that predicts branching.

The variables included were (1) the average investment made by a VC firm in a biotechnology startup in the county of the firm, (2) the number of buyout and acquisition transactions in a year in the firm's county, and (3) the amount of annual federal funding grants received in the firm's county. The relevance of the instrument variables is obtained by the Fstatistic of the instruments which was 12.5. After estimating the first stage probit model with branching as a dependent variable, we generated the Inverse Mills Ratio in STATA 9.0 using the code by Hamilton and Nickerson (2003). In the second-stage model, we introduce the Inverse Mills Ratio in place of the branching variable as an instrumented branching variable. When we use the instrumented branching variable, we find that the results are qualitatively similar to branching as a count variable (results are available from the authors).

Since we have more instruments than the instrumented variable, we also conduct an over identification test (Stock \& Watson, 2003). The chi-square statistic is 0.78 , insignificant from zero $(\mathrm{p}=0.68)$ with two degrees of freedom. Consequently, over identification is not rejected and all instruments are empirically sufficient and ought to be included in the estimation. The multiple alternative estimations we use, i.e. controlling for sample selection and endogeneity; using different operationalizations of the dependent variable; and alternative versions of branching distance variables, all yield qualitatively similar results. In sum, we took adequate precautions to ensure appropriate interpretation of the results described below.

\section{RESULTS}

In Table 1, we report the descriptive statistics of the key variables by age of the firm using three age cohorts. Though entirely possible that startups may be formed to exploit an 
entrepreneurial opportunity drawn from distant technological domains, our data captures this distance by comparing the firm's second patent application to its first application. Also, we see that branching into a new technological niche is not necessarily prevalent only in mature firms. In our sample, $7 \%$ of firms branched in the first year after incorporation, increasing to $26 \%$ and $38 \%$ in years two and three. On average, $41 \%$ of the firms entered a new technological niche every year. In Table 2, we provide the descriptive statistics and correlations for all the variables used in this study.

Insert Tables 1 - 3 and Figures 1 - 4 Here

Hypotheses $1 \mathrm{a}$ and $1 \mathrm{~b}$ predict the main effects of branching on innovative output and impact. The coefficients for branching linear $(b=1.924$ and $p<.001$ in Model 3, Table 3) and squared term $(b=-.243, p<.001)$ are positive and negative respectively suggesting an inverse ' $U$ ' shaped relationship as predicted. For branching and impact, we find that coefficient of the linear term is positive and significant $(b=3.036, p<.001$ in Model 6 , Table 3$)$ and squared term is negative and significant $(\mathrm{b}=-.666, \mathrm{p}<.001)$. The plots in Figures 1 and 2 support our predictions $^{2}$.

Hypothesis 2 a suggests a positive moderation by firm age on the relationship between branching and innovative output (Model 3, Table 3). Since we have a non-linear model (Poisson) and non-linear interaction terms, we cannot determine significance from simple estimates (Wiersema \& Bowen, 2009). Instead, we employ a delta method to derive standard errors for marginal effects of branching at different ages and then examine the difference of marginal

\footnotetext{
${ }^{2}$ Figure 1 is drawn using the coefficient estimates from Model 3 (Table 3) and Figure 2 uses estimates from Model 6 (Table 3). We follow Aiken, West and Reno (1991) by holding all other variables in the estimation at their mean (average) values and plot the main effect of the branching variable on innovative output (Figure 1) and impact (Figure 2).
} 
effects between older and younger firms. This method is useful when standard errors of estimates are not linearly derived (Wooldridge, 2001: p. 44). First, we estimate the marginal effect of branching from zero into one new domain on innovative output for both younger and older firms. This marginal effect is 5.5 and 20.2 for younger and older firms respectively and is statistically different from zero (both at $\mathrm{p}<.01$ ). Then, we follow the same delta method to test if the slope of the line for older firms is statistically different from the slope of the line for younger firms. The t-statistic is significant at $\mathrm{p}<.01$ level. We also test when firms branch from 1 to 2 niches, and from 2 to 3 niches, for younger and older firms and find similar results. There is, however, no significant difference in output as younger and older firms branch from 3 to 4 niches $(p<.15)$. To summarize, older firms have a higher increase in output (slope) when they enter one to three niches (mean plus two standard deviations). This evidence supports the positive moderation of firm age of the relationship between branching and output, when firms enter up to three new domains and no statistically significant difference thereafter (Figure 3).

Hypothesis $2 \mathrm{~b}$ predicts a negative moderation effect of firm age on the relationship between branching and impact (Model 6, Table 3). That is, younger firms will have stronger increases in impact from branching than older firms. We use the method outlined above to assess the marginal effects and their difference. When younger firms branch from zero into one niche, their impact increases from 1.7 to 6.8 , and for older firms it increases from 1.4 to 2.2. Both marginal effects and difference between the two marginal effects are statistically significant at $\mathrm{p}<.05$. The steepest increase occurs when younger firms expand from one to two new niches. For younger firms, impact increases from 6.8 to 12.9 , and for older firms, it increases from 2.2 to 2.9 when entering two technical niches. When firms entered three niches, there is decline in impact for younger firms (12.9 to 11.2) and a marginal increase for older firms (2.9 to 3.2). This 
suggests that the positive moderation for younger firms extends only up to branching into two niches (Figure 4).

Whereas our results appear to support the curvilinear relationship between branching and the dependent variables, the mean value of branching is 0.7 , and not many firms branch into more than 4 technology niches in a given window. We conducted additional analyses to check if our results are driven by one or two firms branching into many niches. We find that the curvilinear inflection point occurs when branching from four to five niches, for innovative output, and from two to three niches, for impact. We find that 55 unique firms, $40 \%$ of our sample, branch into three or more niches. Consequently, the results of the impact variable are not driven by a few firms branching often. For innovative output, 13 firms or $10 \%$ of our sample branch into five or more niches, and may likely influence the curvilinear pattern for output.

\section{DISCUSSION}

This study adds to the literature by examining how the patterns of exploration by young and older firms have different implications for the quantity and technological impact of the firm's innovative activity. The results highlight the critical role of timing on capability development, i.e., when do organizations benefit from expanding their investments in technological capabilities? Recent theoretical arguments posit that startups face a dilemma on whether to invest upfront in the development of capabilities that strain the resource-constrained young firm or have a more gradual investment in capabilities (Sapienza et al., 2006). Similarly, researchers also question the import of timing of capability development and reconfiguration in mature firms (Helfat and Peteraf, 2003; Lavie, 2006). In a theoretical account of early internationalization of startups, Sapienza et al. (2006) argue that investments in developing new capabilities to enter international markets may decrease short term survival prospects but 
increase long term growth potential of these nascent organizations. In contrast, older firms tend to produce incremental innovative output and may consider expanding their technological capabilities by entering new niches to revitalize their R\&D and product pipelines (Ahuja and Lampert, 2001). Our study reveals that when firms enter two new technological niches, younger firms benefit greatly by enhanced impact ( 7.6 times more citations than younger firms that do not branch) and older firms are able to generate more output (2.1 times more output than older firms that do not branch).

The results provide evidence to bolster Zott (2003)'s simulation study which found that firms that invested in early capability development sustained superior performance advantages in subsequent years. Even in the resource-constrained environments of startups (George, 2005), we find that the early expansion of technological capabilities by entry into two new technological niches accrue significant advantages by enhancing innovative output (from 1.8 to 19.7 patents). Earlier, we discussed the nearly seven-fold increase in impact for startups. Taken together, branching increases both output and impact in younger firms, though the magnitude of benefits for impact is manifestly higher than output. Therefore, the age at which investments in expanding technological capabilities are made, indeed, influences the nature of the payoffs that accrue to such investments.

Older firms are able to generate greater increase in quantity of innovative output from entering two niches when compared to younger firms (1.6 times more patents). Although older firms double (from 1.4 to 2.9 ) their impact by entering two technical niches, they have a lower boost from branching when compared to younger firms (1.7 vs. 12.9 citations per patent). It is important though to consider the doubling of impact when older firms branch out relative to 
those that do not. Consequently, even for older firms, branching is a mechanism that enables them to increase impact and output.

We find evidence for optimal patterns for technological expansion as conditional upon organizational age. In the entrepreneurship literature, this learning from newness is an important source of competitive advantage (Autio et al, 2001; Sorensen and Stuart, 2000). Understanding technological capabilities in startups and their capacity to spawn high impact inventions is fundamental to the study of entrepreneurship and innovation. Few studies account for capability development in startups; even fewer use longitudinal data to study their temporal effects. This study provides unique insights into factors that influence the quantity and impact of innovative output in startups.

In spite of this study's advantages, it suffers from a few limitations. First, we control for resource endowment by including measures for knowledge stock, partnering behavior, and access to equity markets. We have no direct measure for resource munificence or constraints, which could influence the pattern and pacing of capability development. Second, we do not theorize why some firms branch into niches while others do not. Our arguments evaluate the effects of branching on innovative output rather than discern the rationale for entering specific niches. Though we robustly control for unobserved factors that lead to branching, there is a gap in our understanding on why firms branch out, a useful avenue for further research.

Third, our moderation arguments focus on the relative advantages of young versus older firms from entry into new technological niches controlling for the distance of such domains. Though we have listed several causal mechanisms that hinder or promote innovation from entering new niches, we lack specific guidance from prior literature on the relative magnitude of each of these causal mechanisms. Hence, we have assumed that when a greater number of factors 
favor older or younger firms, then these firms indeed fare better. This may not be the case; for example, we have limited information on whether the magnitude of the deleterious effects of rigid mental models or lack of communication in mature firms compared to the benefits provided by its higher absorptive capacity. A fruitful area for research could be to measure and test the relative magnitude of the causal mechanisms such as the degree to which resource constraints hamper investments in innovation in startups or the ossifying effect of rigid mental models or routinization in more mature firms. Finally, we use patent-derived measures for technological capabilities. Though appropriate for this study, the use of patent-based measures captures a central, albeit partial, facet of a technological capability. An extension of this study might consider finer-grained measures to articulate richer causal explanations on why startups enter new niches and how these firms direct their search behavior. Additional measures may include the publication data of scientists, the complementary assets of partners, and the capital investments in developing products, among others.

Limitations aside, we systematically examined the influence of branching on innovative returns for firms. Our findings add to the entrepreneurship literature by suggesting conditions under which innovative output is influenced by firm age. The results encourage future research into the study of knowledge recombination and the discovery of entrepreneurial opportunities as well as the temporal dynamics of capability development and its performance consequences. 


\section{ACKNOWLEDGEMENTS}

An earlier version of this paper was published in the Best Paper Proceedings of the Academy of Management. The comments of Connie Helfat and two anonymous referees helped improve the quality of this manuscript. We thank the seminar participants at ISB, London Business School, and Will Mitchell for comments on earlier versions. This research was supported by the Advanced Institute of Management (AIM) Innovation Fellowship (ESRC RES 331-27-0011). 


\section{REFERENCES}

Ahuja, G, Lahiri, N. 2006. Does vertical integration impact technology search? Evidence from the semiconductor industry, Working Paper, University of Michigan.

Ahuja, G, Lampert, CM. 2001. Entrepreneurship in the large corporation: A longitudinal study of how established firms create breakthrough inventions, Strategic Management Journal, 22: 521-543.

Aiken, L., West, S., Reno, R. 1991. Multiple regression: Testing and interpreting interactions. Thousand Oaks, CA: Sage.

Autio, E, Sapienza, HJ, Almeida, JG. 2000. Effects of age at entry, knowledge intensity, and imitability on international growth, Academy of Management Journal, 43: 909 - 924.

Amabile, TM. 1988. A model of creativity and innovation in organizations, Research in Organizational Behavior, 10: 123-167.

Argote L. 1999. Organizational learning: Creating, retaining and transferring knowledge. Boston, MA: Kluwer Academic Publishing.

Argyres, NS, Silverman, BS. 2004. R\&D, Organization structure, and the development of corporate technological knowledge, Strategic Management Journal, 25(8-9): 929-958.

Balasubramanian, N., \& Lee, J. 2008. Firm age and innovation, Industrial and Corporate Change, 17(5): 1019-1047.

Barron, DN, West, E, Hannan, MT. 1994. A time to grow and a time to die - Growth and mortality of credit unions, American Journal of Sociology, 100(2): 381-421.

Basalla, G. 1988. The Evolution of Technology. Cambridge University Press: Cambridge, MA.

Cohen, J, Cohen, P, West, SG, Aiken, LS. 2003. Applied Multiple Regression/Correlation Analysis for the Behavioral Sciences, 3rd ed. Hillsdale: Erlbaum

Cohen, WM, Levinthal, DA. 1990. Absorptive-capacity - A new perspective on learning and innovation. Administrative Science Quarterly, 35(1): 128-152.

Dushnitsky, G, Lenox, MJ. 2005. When do firms undertake R\&D by investing in new ventures?, Strategic Management Journal, 26(10): 947-965.

Ethiraj, S, Puranam, P. 2004. The distribution of R\&D effort in systemic industries: Implications for competitive advantage. In J. Baum and A. McGahan, Eds., Business Strategy over the Industry Life Cycle, Advances in Strategic Management 21. Oxford, UK: Elsevier Press.

Fan, T. 2010. De novo venture strategy: Arch incumbency at inaugural entry. Strategic Management Journal, 31: 19-38

Fleming, L. 2001. Recombinant uncertainty in technological search, Management Science, 47(1): 117-132.

Fleming, L, Sorenson, O. 2004. Science as a map in technological search, Strategic Management Journal, 25(8-9): 909-928.

George, G. 2005. Slack resources and the performance of privately held firms, Academy of 
Management Journal, 48(4): 661-676.

George, G., Kotha, R., Zheng, Y. 2008. The puzzle of insular domains: a longitudinal study of knowledge structuration and innovation in biotechnology firms. Journal of Management Studies, 45: 1448 - 1474.

George, G., Zahra, S., Wood, D. 2002. The effects of business-university alliances on innovative output and financial performance: A study of publicly traded biotechnology companies, Journal of Business Venturing, 17(6): 577-609.

Gilad, B. 1984. Entrepreneurship - the issue of creativity in the marketplace, Journal of Creative Behavior, 18(3): 151-161

Greene, W. 1998. Econometric Analysis. Prentice Hall: New Jersey.

Griliches, Z. 1990. Patent statistics as economic indicators - A survey, Journal of Economic Literature, 28(4): 1661-1707.

Hall, BH, Jaffe, A, Trajtenberg, M. 2005. Market value and patent citations, RAND Journal of Economics, 36(1): 16-38.

Hamilton B, Nickerson J. 2003. Correcting for endogeneity in strategic management research, Strategic Organization, 1: 53-80

Helfat, CE., Peteraf, M. 2003. The dynamic resource-based view: Capability lifecycles, Strategic Management Journal, 24(10): 997-1010.

Henderson, R. 1993. Underinvestment and incompetence as responses to radical innovation Evidence from the photolithographic equipment industry, RAND Journal of Economics, 24(2): 248-270.

Henderson, R, Cockburn, I. 1994. Measuring competence: Exploring firm effects in pharmaceutical research, Strategic Management Journal, 15: 63-84.

Huang, K, Murray, F. 2009. Does Patent Strategy Shape the Long-run Supply of Public Knowledge? Evidence from Human Genetics. Academy of Management Journal. 11931221

Kaplan, S, Murray, F, Henderson, R. 2003. Discontinuities and senior management: Assessing the role of recognition in pharmaceutical firm response to biotechnology, Industrial and Corporate Change, 12(2): 203-233.

Katila, R, Ahuja, G. 2002. Something old, something new: A longitudinal study of search behavior and new product introduction, Academy of Management Journal, 45(6): 11831194.

Kogut, B, Zander, U. 1992. Knowledge of the firm, combinative capabilities, and the replication of technology, Organization Science, 3(3): 383-397.

Lacetera, N, Cockburn, IM, Henderson, R. 2004. Do firms change capabilities by hiring new people? A study of the adoption of science-based drug discovery. In J. Baum and A. McGahan, Eds., Business Strategy over the Industry Life Cycle, Advances in Strategic Management 21. Oxford, UK: Elsevier Press.

Lavie, D. 2006. Capability reconfiguration: An analysis of incumbent responses to technological 
change, Academy of Management Review, 31(1): 153-174.

Lee, F., Edmondson, A. C., Thomke, S., \& Worline, M. 2004. The mixed effects of inconsistency on experimentation in organizations, Organization Science, 15: 310-326.

Lerner, J. 1994. The importance of patent scope: an empirical analysis, RAND Journal of Economics, 25(2): 319-333.

March, JG. 1991. Exploration and exploitation in organizational learning, Organization Science, 2: 71-87.

Mosakowski, E.1998. Entrepreneurial resources, organizational choices, and competitive outcomes, Organization Science, 9(6): 625-643.

Nelson, RR, Winter, SG. 1982. An Evolutionary Theory of Economic Change. Cambridge, MA: Belknap Press.

Nerkar, A. 2003. Old is gold? The value of temporal exploration in the creation of new knowledge, Management Science, 49(2): 211-229.

Nohria, N, Gulati, R. 1996. Is Slack Good or Bad for Innovation?, Academy of Management Journal, 39(5): 1245-1264.

Penrose, E.1959. The Theory of the Growth of the Firm. New York: Wiley.

Phene, A, Fladmoe-Lindquist,K, Marsh, L. 2006. Breakthrough innovations in the US biotechnology industry: the effects of technological space and geographic origin, Strategic Management Journal, 27(4): 369-388.

Pisano, GP. 1994. Knowledge, integration, and the locus of learning - An empirical-analysis of process-development, Strategic Management Journal, 15: 85-100.

Powell, WW, Koput, KW, Smith-Doerr, L. 1996. Inter-organizational collaboration and the locus of innovation: Networks of learning in biotechnology, Administrative Science Quarterly, 41(1): 116-145.

Powell, WW, White, DR, Koput, KW, Owen-Smith, J. 2005. Network dynamics and field evolution: The growth of inter-organizational collaboration in the life sciences, American Journal of Sociology, 110(4): 1132-1205.

Rosenkopf, L, Nerkar, A. 2001. Beyond local search: Boundary-spanning, exploration, and impact in the optical disk industry, Strategic Management Journal, 22(4): 287-306.

Rothaermel, F. T., Boeker, W. 2008. Old technology meets new technology: Complementarities, similarities, and alliance formation, Strategic Management Journal, 29(1): 47-77.

Sampson, RC. 2005. Experience effects and collaborative returns in R\&D alliances, Strategic Management Journal, 26(11):1009-1031.

Sapienza, HJ, Autio, E, George, G, Zahra, S. 2006. A capabilities perspective on the effects of early internationalization on survival and growth, Academy of Management Review, 31(4): 914-933.

Schumpeter, JA. 1939. Business Cycles. New York: McGraw-Hill.

Shan, WJ, Walker,G, Kogut, B. 1994. Interfirm cooperation and startup innovation in the 
biotechnology industry, Strategic Management Journal, 15(5): 387-394.

Sorensen, JB, Stuart, TE. 2000. Aging, obsolescence, and organizational innovation, Administrative Science Quarterly, 45(1): 81-112.

Stinchcombe, A. 1965. Social structure and organizations. In J.G. March, Handbook of Organizations, 142-193, Chicago: Rand McNally.

Stock, J \& Watson, M. 2003. Introduction to Econometrics, The Addison-Wesley Series in Economics, 2nd Edition, Reading, MA: Addison Wesley.

Stuart, TE. 2000. Inter-organizational alliances and the performance of firms: A study of growth and innovation rates in a high-technology industry, Strategic Management Journal, 21(8): 791-811.

Whiting, BG. 1988. Creativity and entrepreneurship - How do they relate?, Journal of Creative Behavior, 22(3): 178-183.

Yayavaram, S., \& Ahuja, G. 2008. Decomposability in knowledge structures and its impact on the usefulness of inventions and knowledge-base malleability, Administrative Science Quarterly, 53(2): 333-362.

Zahra, SA, George, G. 2002. Absorptive capacity: A review, reconceptualization, and extension, Academy of Management Review, 27(2): 185-203.

Zheng, Y., Liu, J., George, G. 2010. The dynamic impact of innovative capability and inter-firm network on firm valuation: A longitudinal study of biotechnology start-ups, Journal of Business Venturing, doi:10.1016/j.jbusvent.2009.02.001

Zott, C. 2003. Dynamic capabilities and the emergence of intra-industry differential firm performance: insights from a simulation study. Strategic Management Journal, 24: 97125 .

Zucker, LG, Darby, MR, Brewer, MB. 1998. Intellectual human capital and the birth of US biotechnology enterprises, American Economic Review, 88(1): 290-306.

Wooldridge, J.M. 2001. Econometric Analysis of Cross Section and Panel Data. Boston, MA: MIT Press. 


\section{TABLE 1}

Descriptive Statistics by Age of the Firm

\begin{tabular}{|c|c|c|c|c|c|c|c|c|c|c|c|c|}
\hline \multirow[t]{2}{*}{ Variables } & \multicolumn{4}{|c|}{$\begin{array}{c}\text { Age } \leq 5 \text { years } \\
(\mathrm{n}=650)\end{array}$} & \multicolumn{4}{|c|}{$\begin{array}{l}\text { Age } 6 \text { to } 12 \text { years } \\
\quad(n=686)\end{array}$} & \multicolumn{4}{|c|}{$\begin{array}{c}\text { Age }>12 \text { years } \\
(\mathrm{n}=183)\end{array}$} \\
\hline & Mean & s.d. & Min & Max & Mean & s.d. & Min & Max & Mean & s.d. & Min & $\operatorname{Max}$ \\
\hline Innovative Output $_{(t+1, t+2)}$ & 3.77 & 13.08 & 0 & 270 & 5.16 & 12.50 & 0 & 261 & 6.33 & 13.02 & 0 & 77 \\
\hline Technology Impact (5 year window) & 3.21 & 14.58 & 0 & 184 & 4.87 & 12.69 & 0 & 137 & 5.04 & 17.47 & 0 & 172 \\
\hline Branching (2 year window) & 0.55 & 0.93 & 0 & 6 & 0.93 & 1.20 & 0 & 9 & 0.73 & 1.09 & 0 & 6 \\
\hline
\end{tabular}

Note: Data are in firm-years for panel, number of firms $=128$

TABLE 2

Descriptive Statistics and Correlations

\begin{tabular}{|c|c|c|c|c|c|c|c|c|c|c|c|c|c|c|c|c|}
\hline Variables & Mean & Std. Dev. & Min. &. $\mathrm{M}$ & ax. & 1 & 2 & 3 & 4 & 5 & 6 & 7 & 8 & 9 & 10 & 11 \\
\hline 1 Quantity of Innovative Output & 4.5 & 13.2 & & 0 & 270 & 1 & & & & & & & & & & \\
\hline 2 Technology Impact & 4.2 & 14.2 & & 0 & 184 & .01 & 1 & & & & & & & & & \\
\hline 3 Knowledge Stock & 5.0 & 11.7 & & 0 & 265.8 & .52 & .18 & 1 & & & & & & & & \\
\hline 4 Number of Alliances $(t)$ & 0.6 & 1.0 & & 0 & 9 & .28 & .08 & .28 & 1 & & & & & & & \\
\hline 5 Prior Alliances $(\mathrm{t}-1 \ldots . . \mathrm{t}-\mathrm{n})$ & 3.0 & 4.3 & & 0 & 27 & .23 & .10 & .45 & .29 & 1 & & & & & & \\
\hline 6 Achieved IPO & 0.6 & 0.5 & & 0 & 1 & .15 & .07 & .25 & .10 & .41 & 1 & & & & & \\
\hline 7 Depth of capabilities & 2.5 & 6.2 & & 0 & 71 & .27 & .09 & .54 & .10 & .46 & .30 & 1 & & & & \\
\hline 8 Breadth of capabilities & 1.1 & 1.7 & & 0 & 12 & .33 & .23 & .59 & .14 & .45 & .40 & .65 & 1 & & & \\
\hline 9 Age & 6.9 & 4.2 & & 1 & 18 & .09 & .09 & .27 & .03 & .50 & .62 & .47 & .48 & 1 & & \\
\hline 10 Branching & 0.7 & 1.1 & & 0 & 9 & .28 & .23 & .33 & .13 & .19 & .21 & .10 & .26 & .13 & 1 & \\
\hline 11 Branching Distance & 0.1 & 0.2 & & 0 & 0.9 & .15 & .19 & .10 & .07 & .09 & .12 & -.04 & .07 & .05 & .47 & \\
\hline
\end{tabular}

Year dummies not reported, Number of observations $=1519$. All correlations greater than .08 are significant at .001 level. 
TABLE 3

Fixed-Effects Poisson Regression

\begin{tabular}{|c|c|c|c|c|c|c|c|c|c|c|c|c|}
\hline \multirow[t]{2}{*}{ Dependent Variable } & \multicolumn{6}{|c|}{ Innovative Output (Patent Count) } & \multicolumn{6}{|c|}{ Technology Impact (Citations Received/Output) } \\
\hline & \multicolumn{2}{|c|}{ Model 1} & \multicolumn{2}{|c|}{ Model 2} & \multicolumn{2}{|c|}{ Model 3} & \multicolumn{2}{|c|}{ Model 4} & \multicolumn{2}{|c|}{ Model 5} & \multicolumn{2}{|c|}{ Model 6} \\
\hline Knowledge Stock & $.004 * * *$ & $(.001)$ & $.003 * * *$ & $(.001)$ & $.003 * * *$ & $(.001)$ & $.009 * * *$ & $(.001)$ & $.006 * * *$ & $(.001)$ & $.009 * * *$ & $(.001)$ \\
\hline Number of Alliances $(\mathrm{t})$ & $.066^{* * *}$ & $(.010)$ & $.068 * * *$ & $(.010)$ & $.080 * * *$ & $(.010)$ & $.044 * * *$ & $(.012)$ & $.055 * * *$ & $(.012)$ & $-.040 * *$ & $(.014)$ \\
\hline Prior Alliances (t-1...t-n) & $.060 * * *$ & $(.008)$ & $.058 * * *$ & $(.008)$ & $.063 * * *$ & $(.008)$ & $-.016^{*}$ & $(.007)$ & -.009 & $(.007)$ & $-.045 * * *$ & $(.007)$ \\
\hline Achieved IPO & .005 & $(.059)$ & .063 & $(.059)$ & .068 & $(.060)$ & .019 & $(.053)$ & .026 & $(.054)$ & -.002 & $(.055)$ \\
\hline Depth of capabilities & $-.007 *$ & $(.003)$ & -.003 & $(.003)$ & .005 & $(.003)$ & $-.017 * * *$ & $(.003)$ & $-.014 * * *$ & $(.003)$ & -.003 & $(.003)$ \\
\hline Breadth of capabilities & $-.048 * * *$ & $(.012)$ & -.019 & $(.012)$ & -.001 & $(.013)$ & $.222 * * *$ & $(.011)$ & $.252 * * *$ & $(.011)$ & $.251 * * *$ & $(.012)$ \\
\hline Age & $.451 * * *$ & $(.024)$ & $.404 * * *$ & $(.025)$ & $.758 * * *$ & $(.036)$ & $.051 * *$ & $(.019)$ & .007 & $(.020)$ & $.226 * * *$ & $(.026)$ \\
\hline Age-sq. & $-.016 * * *$ & $(.001)$ & $-.015 * * *$ & $(.001)$ & $-.034 * * *$ & $(.002)$ & $-.004 * * *$ & $(.001)$ & $-.003 * *$ & $(.001)$ & $-.013 * * *$ & $(.001)$ \\
\hline Distance & $2.856 * * *$ & $(.243)$ & $2.381 * * *$ & $(.255)$ & $1.944 * * *$ & $(.257)$ & $4.952 * * *$ & $(.224)$ & $4.074 * * *$ & $(.237)$ & $3.938 * * *$ & $(.245)$ \\
\hline Distance-square & $-2.596 * * *$ & $(.352)$ & $-2.214 * * *$ & $(.357)$ & $-1.840 * * *$ & $(.356)$ & $-3.197 * * *$ & $(.305)$ & $-2.386^{* * *}$ & $(.312)$ & $-2.703 * * *$ & $(.317)$ \\
\hline Branching & & & $.238 * * *$ & $(.030)$ & $1.924 * * *$ & $(.140)$ & & & $.150 * * *$ & $(.013)$ & $3.036 * * *$ & $(.128)$ \\
\hline Branching -square & & & $-.036 * * *$ & $(.006)$ & $-.243 * * *$ & $(.033)$ & & & & & $-.666 * * *$ & $(.033)$ \\
\hline Age* Branching & & & & & $-.419 * * *$ & $(.035)$ & & & & & $-.523 * * *$ & $(.030)$ \\
\hline Age-sq.*Branching & & & & & $.021 * * *$ & $(.002)$ & & & & & $.023 * * *$ & $(.002)$ \\
\hline Age* Branching-sq. & & & & & $.054 * * *$ & $(.008)$ & & & & & $.117 * * *$ & $(.008)$ \\
\hline Age-sq. *Branching-sq. & & & & & $-.003 * * *$ & $(.000)$ & & & & & $-.005 * * *$ & $(.000)$ \\
\hline Year dummies & Included & & Included & & Included & & Included & & Included & & Included & \\
\hline Chi-square & 3255.1 & & 3290.4 & & 3145.4 & & 3822.5 & & 3881.4 & & 4341.8 & \\
\hline Log likelihood & -2520.3 & & -2486.0 & & -2327.5 & & -6527.8 & & -6463.8 & & -6057.3 & \\
\hline Chi-square change & & & $66.69 * * *$ & & $289.48 * * *$ & & & & $448.62 * * *$ & & $427.30 * * *$ & \\
\hline
\end{tabular}

Standard errors in parentheses

${ }^{*} p<0.05,{ }^{* * *} p<0.01,{ }^{* * *} p<0.001$ 
Figure 1: Main Effect of Branching on Innovative Output

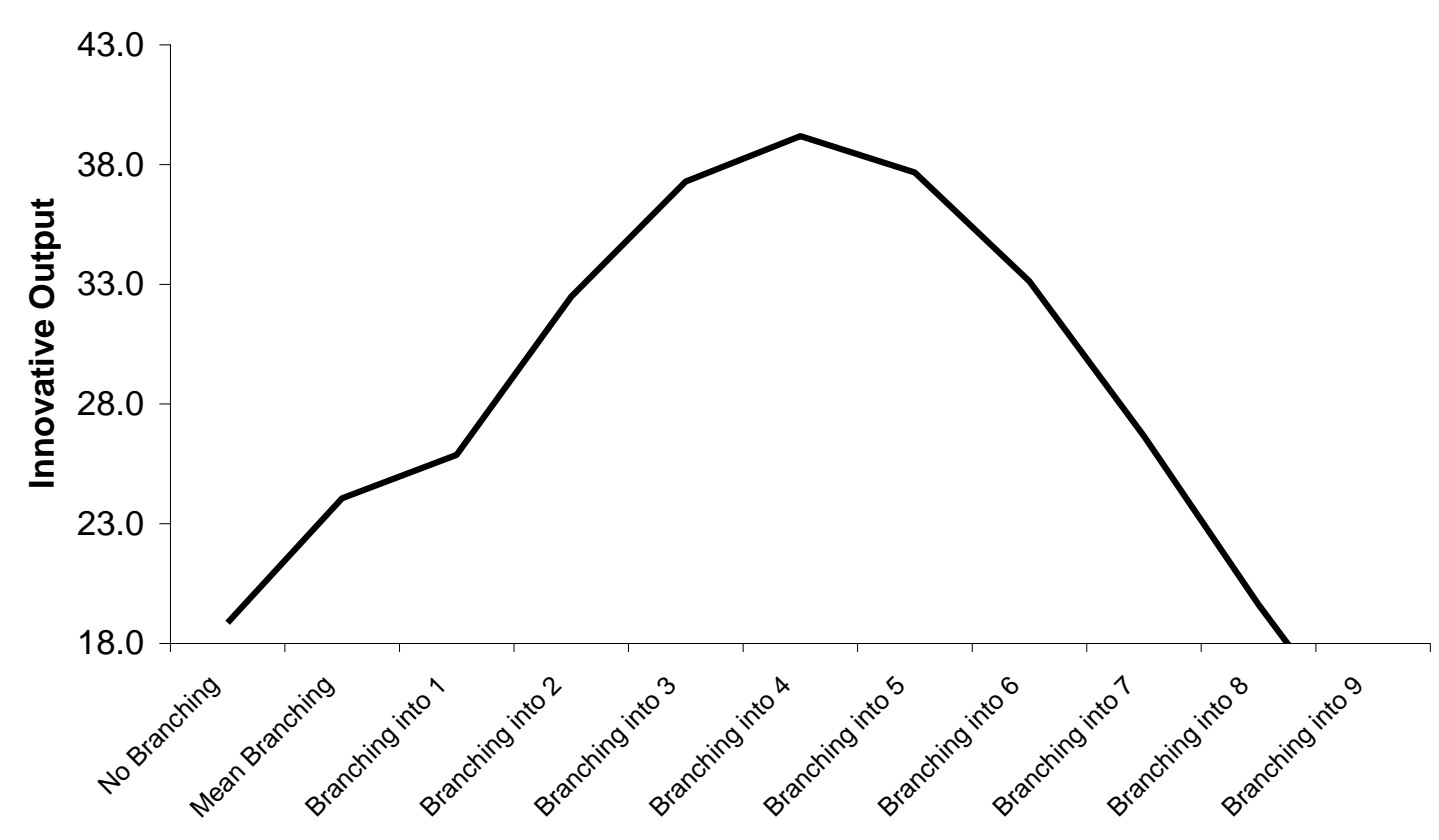

Figure 2: Main Effect of Branching on Impact

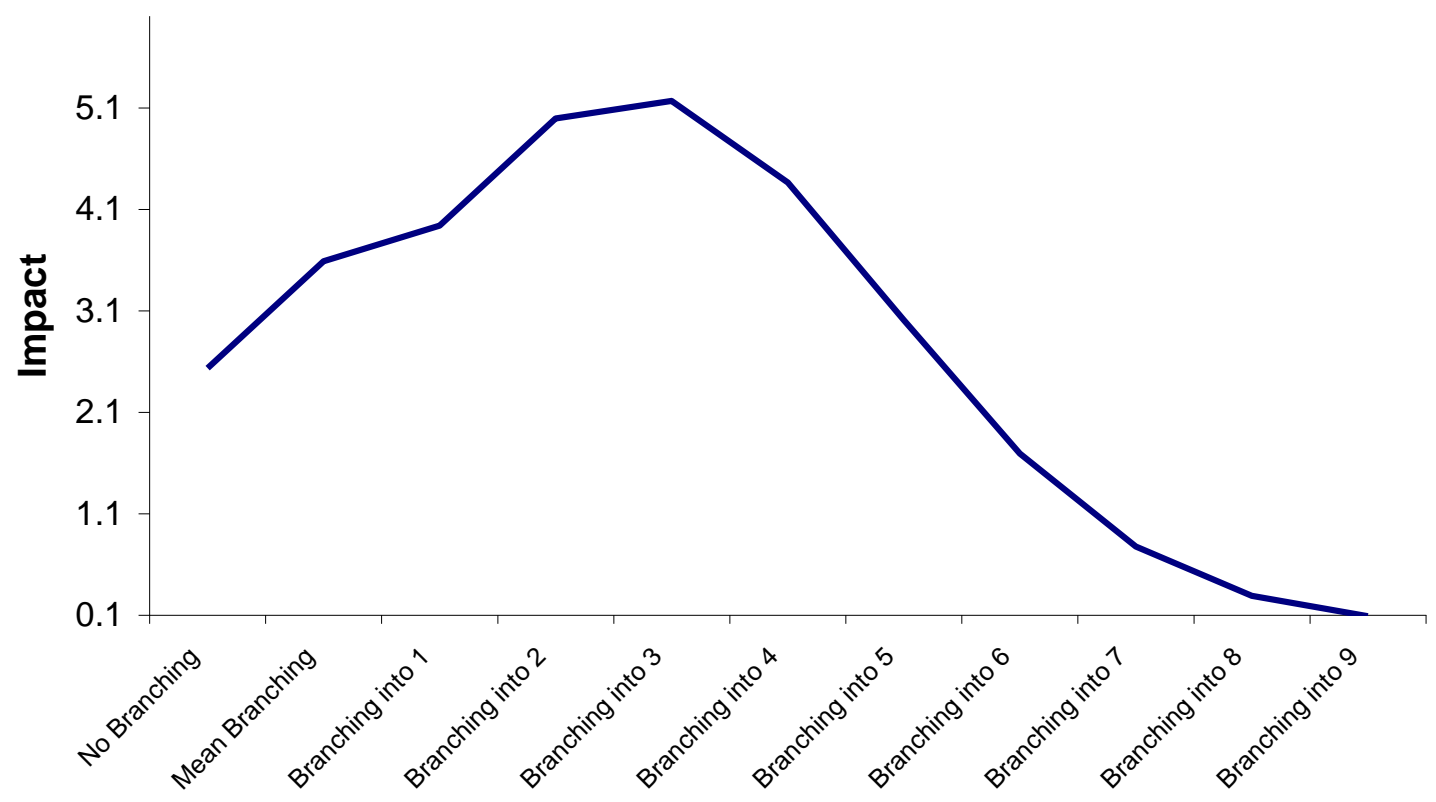


Figure 3: Moderation by Age of Relationship between Branching and Innovative Output

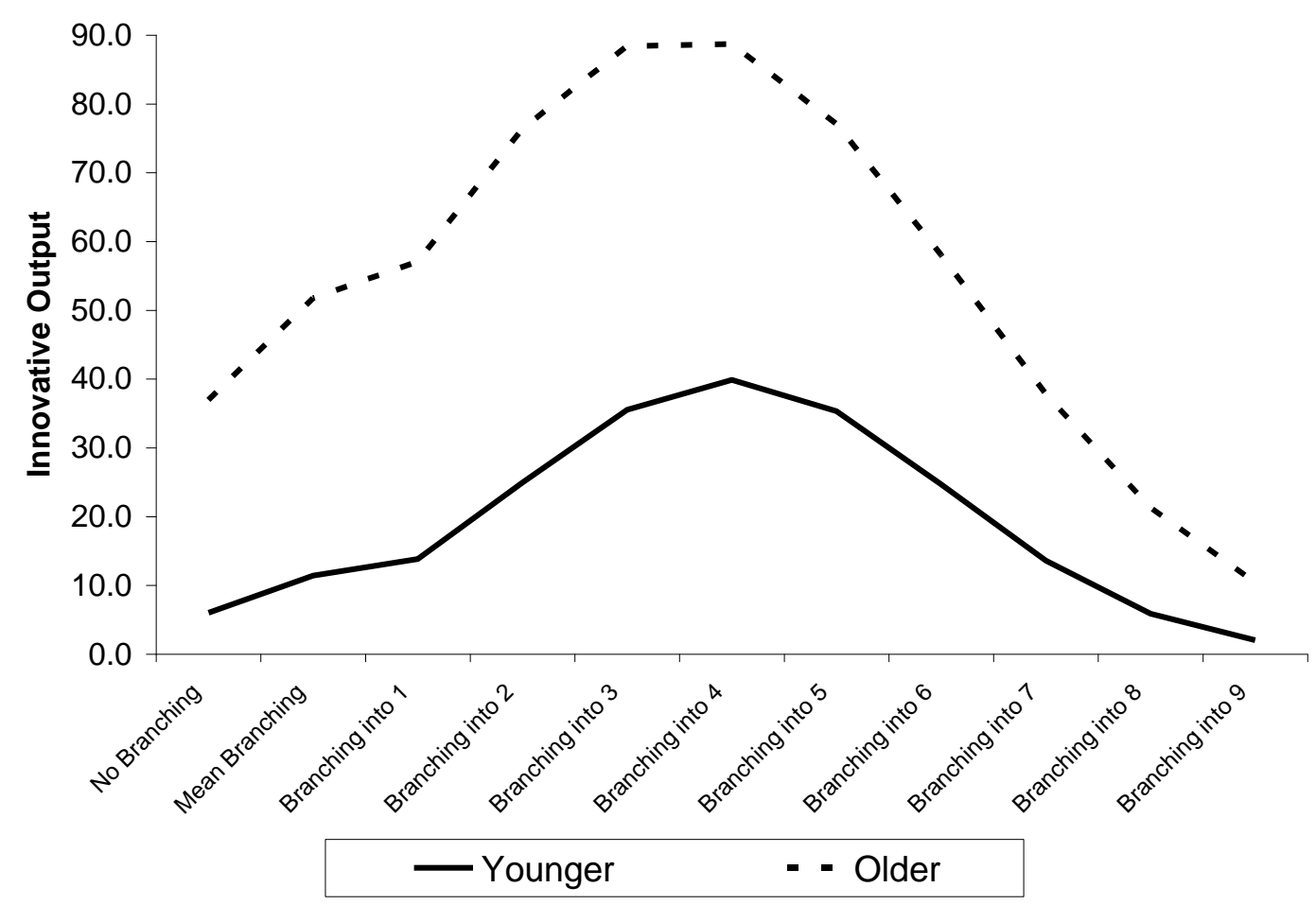

Figure 4: Moderation by Age of Relationship between Branching and Impact

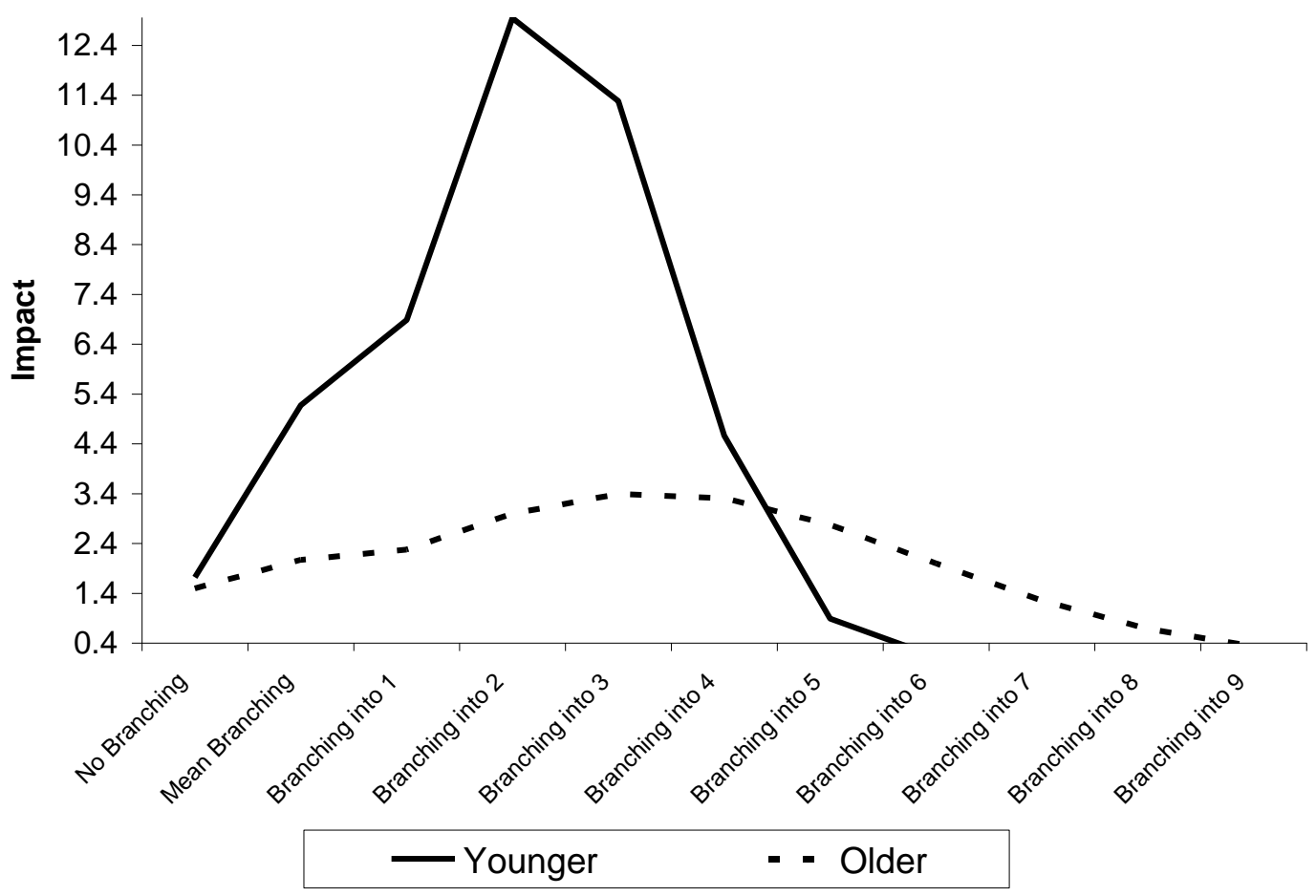

